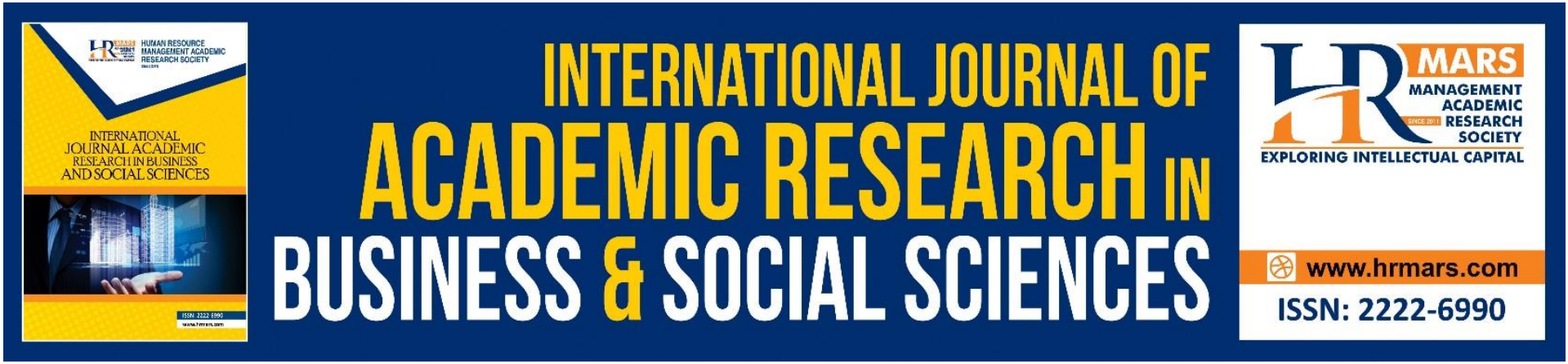

\title{
An Investigation of Economic Growth, Youth Unemployment and Inflation In ASEAN Countries
}

Yen Vun Fung, Janice L. H. Nga

To Link this Article: http://dx.doi.org/10.6007/IJARBSS/v12-i1/12023

DOI:10.6007/IJARBSS/v12-i1/12023

Received: 09 November 2021, Revised: 11 December 2021, Accepted: 30 December 2021

Published Online: 16 January 2022

In-Text Citation: (Fung \& Nga, 2022)

To Cite this Article: Fung, Y. V., \& Nga, J. L. H. (2022). An Investigation of Economic Growth, Youth Unemployment and Inflation In ASEAN Countries. International Journal of Academic Research in Business and Social Sciences, 12(1), 1731-1755.

Copyright: @ 2022 The Author(s)

Published by Human Resource Management Academic Research Society (www.hrmars.com)

This article is published under the Creative Commons Attribution (CC BY 4.0) license. Anyone may reproduce, distribute, translate and create derivative works of this article (for both commercial and non0-commercial purposes), subject to full attribution to the original publication and authors. The full terms of this license may be seen at: http://creativecommons.org/licences/by/4.0/legalcode

Vol. 12, No. 1, 2022, Pg. 1731- 1755

Full Terms \& Conditions of access and use can be found at http://hrmars.com/index.php/pages/detail/publication-ethics 


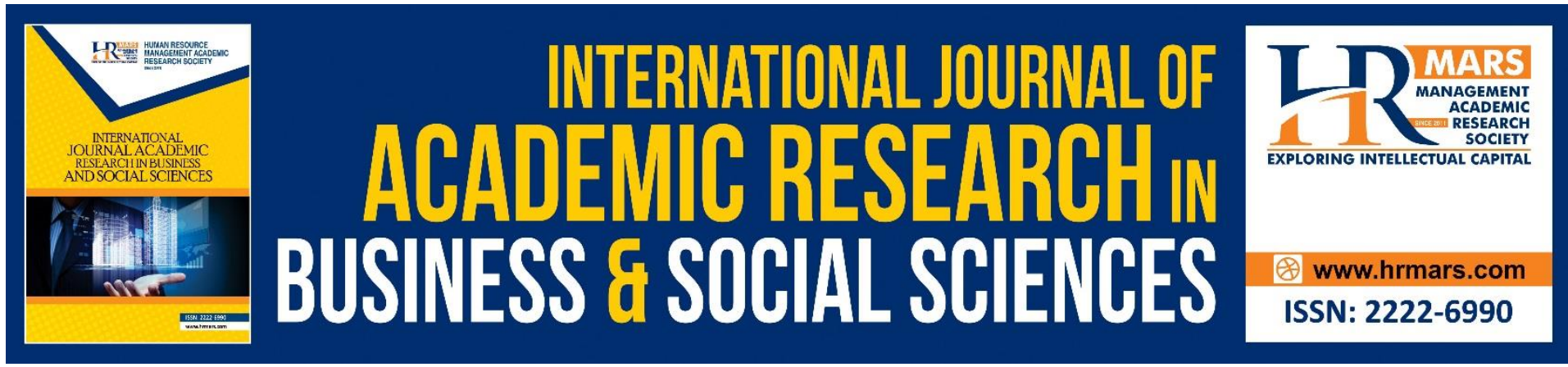

\title{
An Investigation of Economic Growth, Youth Unemployment and Inflation In ASEAN Countries
}

\author{
Yen Vun Fung ${ }^{1}$, Janice L. H. Nga ${ }^{2}$ \\ Faculty of Business, Economics and Accountancy University Malaysia Sabah, \\ Jalan UMS, 88400, Kota Kinabalu, Sabah, Malaysia \\ Email:db1611010t@student.ums.edu.my, janice@ums.edu.my
}

\begin{abstract}
This study examines the relationship and interaction between youth unemployment (YU), inflation (INFLA), and economic growth (GDP)of ASEAN countries: Brunei Darussalam, Cambodia, Indonesia, Lao PDR, Malaysia, Myanmar, Philippines, Singapore, Thailand, and Vietnam from 1996 to 2019. This study aims to examine the relationship between youth unemployment, inflation, and economic growth throughout the selected period. The method of Panel Granger Causality test, Panel unit root test, Panel co-integration test, Mean Group and Pooled Mean Group, and MANOVA test was applied in this study. This study found that in the long run youth unemployment has a significant negative impact where the increase in 1 percent of youth unemployment will decrease 0.24 percent of economic growth. For inflation, the result stated that inflation also has a positive significant impact in the long run which means that the increase 1percent in inflation, it also improves the economic growth by 0.31 percent. As in ASEAN countries, the bidirectional relationship between youth unemployment, inflation and economic growth exist with causality running from youth unemployment and inflation to economic growth in individuals. Lastly, youth unemployment and inflation have an interaction and have a significant effect on economic growth. Therefore, it is recommended that ASEAN countries take the specific policies that are effective and impact youth unemployment, inflation, and economic growth for the ASEAN countries. This research is expected to help enhance youth empowerment quality policies and improve the development of youth employment.
\end{abstract}

Keywords: Economic Growth, Youth Unemployment, ASEAN, Granger Causality, MANOVA.

\section{Introduction}

In fact, unemployment and inflation are two unpredictably connected financial concepts. Over the long period, there have been a number of financial analysts attempting to explain the relationship among the concepts of inflation and unemployment. There are two conceivable clarifications of this relationship which are one within the short term and another within the long term. For short term there is there's a converse relationship between the two (Aminu et al., 2013). 


\section{Youth Unemployment}

In this paper, it is focusing on how youth unemployment and inflation affected the economy in ASEAN countries. Youth employment is one of the important indicators which will affect economic growth. Worldwide, there are approximately 1.3 billion young people with the ages of 15 and 24 that we call youth. Their involvement in the labour market has impacted the socio-economic development for their countries in the long term (International Labour Organization [ILO], 2020). Thus, the youth unemployment rate still can be identified by the fact that its youth unemployment is still the highest rate in other countries especially in Northern Africa and in the Arab States, at around 2.2 and 1.7 times the global rate, respectively. Therefore, it is important to help the youth enter the labour market. The global youth unemployment rate will increase to 0.1 percentage point in 2020 and it will rise further 0.1 percentage point in 2021(ILO, 2020).

As well as in ASEAN, based on Fig.1, it shows that the youth unemployment rate is 3 to 5 times more than the adult unemployment rate in 2019. This is because the unemployed youth are facing the challenge of the stage of social-economic development. Therefore, according to the report of ILO (2019), the main problems of youth unemployment are the large numbers of youth entering the labour markets every year when there is lack of employment opportunities, in particular in poor economies.

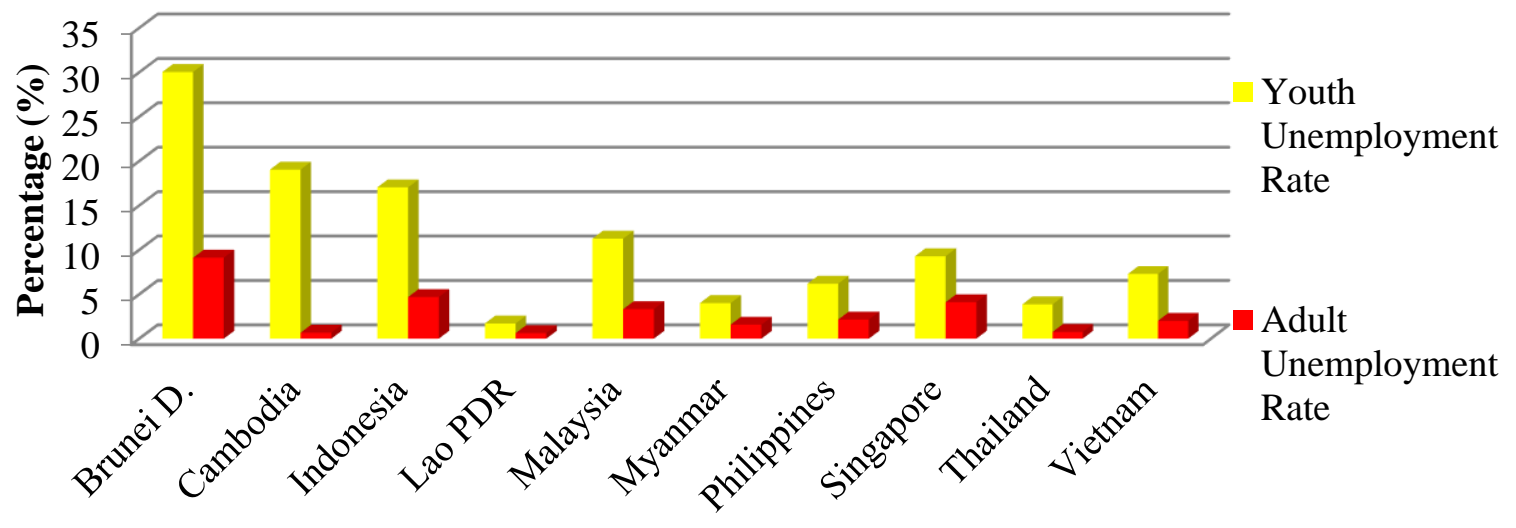

Currently there is an increase in youth unemployment in ASEAN as well. This may be at risk of going into reverse in future as a fourth industrial revolution. The Member States of ASEAN have moved towards high production in export and skill-intensive, reflected in the higher labour of production. The changes vary considerably across the region. There is more demand for high-skill employment in Cambodia, Indonesia, Lao PDR, Philippines, Thailand and Vietnam. The data shows that it has 80 percent of the region's workforce, and is expected to grow by 41 percent or 14 million workers (ILO, 2019) and we also can refer to figure 1.1 which shows that the youth unemployment rate is 3 to 5 times more than the adult unemployment rate in 2019.

\section{Inflation}

The relationship among inflation and economic growth are the subject that has long been intensely discussed and debated in the literature (López-Villavicencio \& Mignon, 2011). A high economic growth in relation with low and stable inflation is the main objective of macroeconomic policy (Khan \& Senhadji, 2001; Seleteng et al., 2013; Vinayagathasan, 2013). The rise of the price of goods and services over time is called inflation. Inflation will cause the 
cost of living to increase. Somehow, it is common but not accurate to define inflation as the increase in the money supply which is a misinterpretation of monetarism's theory (Amadeo, 2018). Inflation also can be defined as the rise of prices for goods or services continuously in a country. There is a condition that the price of goods and services increase over time. Once inflation rises, every currency that you buy with a smaller percentage of goods or services. On the other hand, if the price rises, the money value will fall, that is inflation. Therefore, the value of current or unit of money that is expressed in terms of its purchasing power. When the inflation rate grows, there will be a decrease in the purchasing power of money (Hayes, 2018).

Currently, the degree of social and economic integration of ASEAN members is increasing. Mean for the inflation rates in ASEAN countries were between 0.36 and 16.24 percent in the period 1996-2019. The lowest inflation rates were observed in Brunei Darussalam, Singapore, Malaysia, Thailand, the Philippines and Cambodia with 0.36, 1.44, 2.39, 2.50, 4.37 and 4.86 percent, while the highest were recorded in the Lao People's Democratic Republic and Myanmar were recorded at 16.24 and 16.22 percent, respectively. Inflation rates for Vietnam and Indonesia from 6.15 to 9.38 percent. Meanwhile, ASEAN countries had a rather low per capita real GDP growth rate. Brunei Darussalam recorded the lowest growth rate at 0.62 percent, while Myanmar surpassed the highest growth rate at 8.25 percent. The DPR of Laos, Cambodia and Vietnam were able to reduce the growth rate from 5.18 to 5.45 and 5.65 percent, respectively (see Table 1). Table 1 also shows the preliminary relationships between inflation and growth in the ASEAN countries. Countries such as Singapore, Malaysia, Thailand, the Philippines, and Cambodia recorded moderate growth rates that were accompanied by low long-term inflation.

Table 1: Mean of GDP Growth Rate Per Capita and Mean of Inflation Rate 1996-2019 in ASEAN Countries

\begin{tabular}{|c|c|c|}
\hline & \multicolumn{2}{|c|}{ Mean } \\
\hline & GDP growth rate per capita (\%) & Inflation rate CPI (\%) \\
\hline Brunei Darussalam & -0.617 & 0.362 \\
\hline Cambodia & 5.653 & 4.859 \\
\hline Indonesia & 3.019 & 9.380 \\
\hline Lao PDR & 5.184 & 16.241 \\
\hline Malaysia & 2.962 & 2.391 \\
\hline Myanmar & 8.251 & 16.215 \\
\hline Philippines & 3.225 & 4.374 \\
\hline Singapore & 2.998 & 1.439 \\
\hline Thailand & 2.635 & 2.504 \\
\hline Vietnam & 5.449 & 6.152 \\
\hline
\end{tabular}

Source: Authors Computation

\section{Problem Statement}

Getting a job nowadays is a difficult task for youth. The global recession has left its impact, and after years of decline, youth unemployment rates are rising again (ILO, 2017). Youth unemployment is a growing issue in ASEAN countries, where it was formerly double or triple 
the rate of adult unemployment. Given that many ASEAN populations are still young, addressing youth unemployment in the region is critical (O'Higgins, 2010). Thus, the purpose of this study is to examine how youth unemployment and economic growth interact in ASEAN countries, where the country's economic policies aim to minimise unemployment while maintaining average growth rates.

\section{Objectives of Study}

The specific objectives of the study are:

i. To examine the relationship between youth unemployment, inflation and economic growth in ASEAN countries.

ii. To investigate the causality effect between youth unemployment, inflation and economic growth in ASEAN countries.

iii. To identify any interaction between economic growth, youth unemployment and inflation in ASEAN countries.

\section{Literature Review}

The study by Ihensekhien and Ozemnoka (2017) found that there is the existence of a negative relationship between youth unemployment and economic growth in the panel result meanwhile there is positive relationship between these two variables for the individual countries cases of some countries in Sub-Saharan Africa (SSA). Therefore, the policy of mix needs to be applied which can lead to more investment for the few countries that have positive relationships among the two variables. Somehow, there are changes in employment which were less effective to economic growth in Sweden. Therefore, it causes the high unemployment benefits and other social security programs also offer supplemental income payments for unemployed people who have little track record in the labour force.

Zainul and Hadi (2020) who's finding the determinants of youth unemployment rate in ASEAN countries stated that, GDP, Foreign Direct Investment, inflation Openness, Human Development Index and Population aged 0-14 years are the indicators that will affect the youth unemployment. As a result, the youth unemployment rate is negative and significant with GDP, FDI and inflation. Meanwhile, Openness, the Human Development Index and population aged 0-14 years have positive and significant effects on youth unemployment. Hence, to decrease the youth unemployment in ASEAN, GDP, FDI and inflation must be always on an increasing condition where to provide more opportunities for young workers especially in small and medium enterprises in the country. Furthermore, ASEAN also needs to be concerned about the human development index which will increase the youth unemployment rate once there is an imbalance in the human development index.

Ademola and Badiru (2016), who examine the effects of unemployment and inflation on economic performance in Nigeria, found as a result that there is a long-term relationship with positive relationships between economic growth, unemployment and inflation. This also means the unemployment and inflation delay the expansion of the economy in Nigeria since the matter occurred in Nigeria was within the condition of low income per capita, after all the unemployment rate is high. Nevertheless, the expansion of the economy in Nigeria is called 'Exclusive Growth' which implies it doesn't reflect the living standard for the typical citizen of the country. As a conclusion, the government should take the policy that to extend the extent of productivity on other sectors of the economy not only focused on the oil sector.

According to Al-Sawaie (2020) whose research is finding the relationship between economic growth and unemployment in Jordan with ARDL approach and causality test. From 
the research, we can understand that the appearance of unemployment has affected the economic, social, and political motives. Therefore, the lack of investment to develop the economy causes the fluctuation of economic growth and also employment. As a result, it was found that there is a negative relationship between unemployment and economic growth in Jordan which indicated that when economic growth increased 1 percent, then the unemployment rate would decrease 0.26 percent. In other words, if unemployment increases by 1 percent, it will be expected to lead to a 3.85 percent economic growth decline in the long run. The causality test also concluded that there is a bidirectional relationship from economic growth (GDP) to unemployment in the long term. In contrast, economic growth (GDP) has a negative relationship with unemployment in the short term. Since low economic growth will lead the unemployment increase, the government need to avoid the companies to cut their workers which will tend to reinforces long term unemployment problems.

\section{Theoretical Framework}

According to Okun (1962), it establishes a relationship between the rate of economic growth (GDP) and the rate of unemployment. This rate is dependent on each country's economic condition, it is due to two important factors that are growth of the labour force and the productivity of labour. In general, Okun's findings demonstrated that when unemployment falls, the production of a country will increase. Similarly, a 3 percent increase in economic growth from its long-run level is associated with a 1 percent decrease in unemployment.

\section{The Phillips Curves}

There were various theories examined about the linkage between unemployment and inflation. Therefore, the Phillips curve was divided into four theories which were the negative, the natural hypotheses and, therefore, the positive by the economist Friedman (1976). Keynes maintains his position at the bottom of the Phillips curve and predicts a shift in the Phillips curve's shape. Since the height of the war, professional analysis of the relationship between inflation and unemployment has gone through two phases, and it is now entering a third phase. The adoption of the Philips hypothesis marked the beginning of the process.

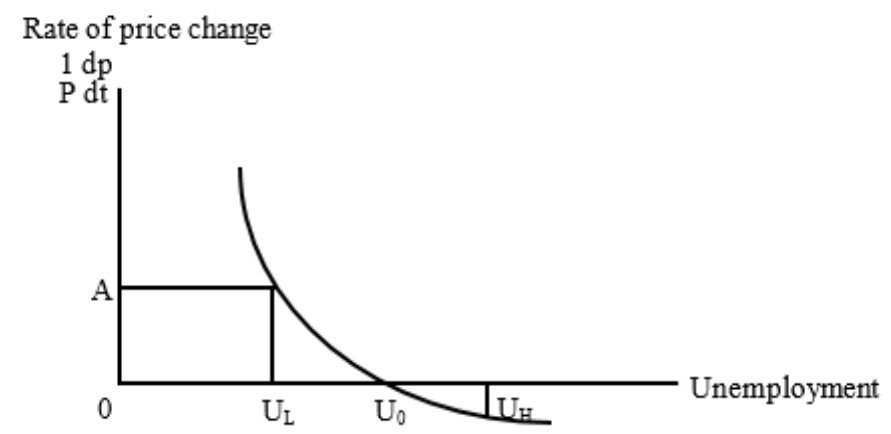

Phillips contests the assumption that there is a stable negative relationship between the growth of unemployment and, consequently, the changes in the wage rate of an individual. Increased unemployment is a result of falling wages, whereas decreased unemployment is a result of increasing wages. When wages changed, the change in costs changed as well, as evidenced by the secular increase in productivity and the treatment of excess price over wage costs being treated as a margin factor that was roughly constant over time.

Fig.2 illustrates this hypothesis, in which Friedman followed the quality practice of relating unemployment to price changes and short-circuiting the intermediate step through 
wages. The condition of this link was generally explained as policy makers offered a stable compromise on the causal link. You can choose an occasional unemployment target; as ul to the value of inflation. In the event that they have to accept the theorem of $A$. The question remains of choosing the measure (monetary tax, perhaps others) that could produce the amount of aggregate nominal demand necessary to achieve the $U_{L}$, but if it were fully covered, the combination of unemployment will be ignored and inflation will be preserved.

Alternatively, policy makers could target a coffee rate or perhaps deflation. In this case they should support higher unemployment $U_{0}$, for zero inflation, $U_{H}$, for deflation Friedman (1976). Economics then took care of extracting the connection shown in Figure 2.1 from the evidence for different countries and time periods, eliminating the effect of external shocks, showing the connection between changes in prices and wages, etc. Furthermore, they examined the social gains and losses from inflation on the contrary, in order to facilitate the selection of the "correct" compromise. Therefore, Okun's law, which is a diminished version of the Phillips postulate, is used as the model specification in this study. The linear relationship between the GDP growth rate, youth unemployment, and the inflation rate is assumed.

\section{Conceptual Framework}

It is a research framework developed to illustrate the relationship between independent variables such as youth unemployment, inflation and economic growth as a dependent variable. According to the linkage of theoretical and empirical data, the relationship between youth unemployment, inflation, and economic growth can be discovered by one economist and confirmed by another. It appears that an endogenous model of economic growth would be the most appropriate theoretical framework for this investigation. According to the model, endogenous factors such as youth unemployment and inflation have the potential to have a significant impact on economic growth (see Fig. 3). It is a widely used growth model that allows for a systematic investigation of government policies and programmes to be carried out by researchers.

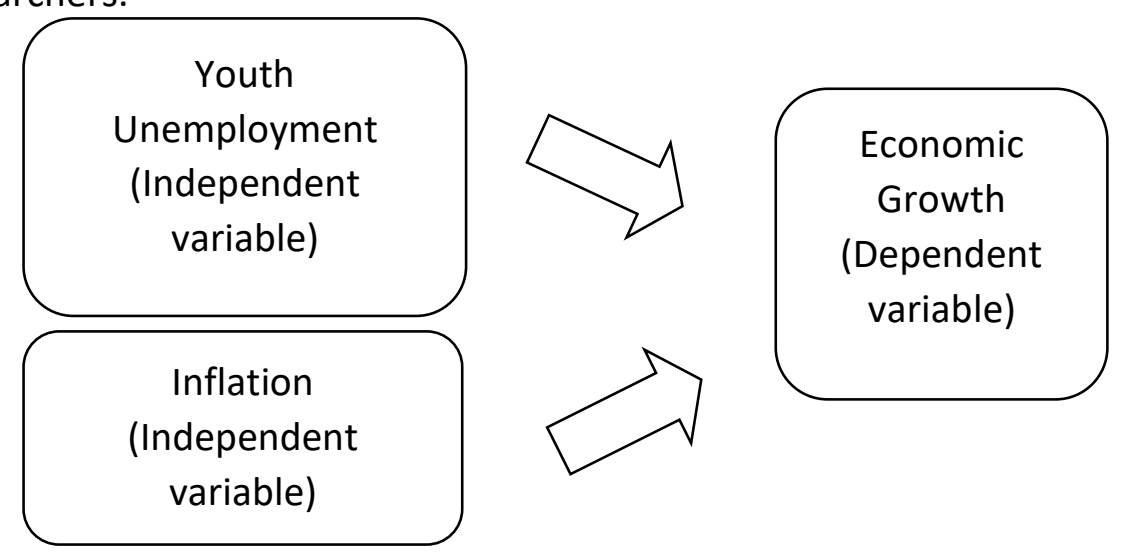

Fig.3: Research Framework Among Economic Growth, Youth Unemployment and Inflation

\section{Methodology}

Firstly, researcher conduct to specify the model of this study. After that the researcher estimate the panel regression model by using Mean group (MG) and Pool mean group (PMG). Then, the diagnostic tests are cross-sectional correlation test, panel unit root tests, crosssection dependence test and panel co-integration tests. Next, Granger causality test applied to investigate the causal relationship between youth unemployment (YU), inflation (INFLA) and economic growth (GDP). Lastly, MANOVA test will be applied to find out the interaction 
among the 3 variables. In. These methodology plays an important role to implement this study accordingly.

\section{Model Specification}

This study used a modified Okun's type model that takes into account unemployment. Inflation is an independent variable, while economic growth is measured by the rate of growth of the Gross Domestic Product (GDP). Okun's law is a diminish version of the Phillips postulate. The GDP growth rate, the unemployment rate, and the inflation rate are assumed to be linearly related. The model for this study is written as follows:

$$
\text { GDP }=f(\text { UNEMPLO, INFLA) }
$$

For this study, we focused on youth unemployment (YU) and the GDP is proxy by purchasing power parity (PPP). Thus, the new imposed model for this study is formulated as follows:

$$
G D P=f(Y U, I N F L A)
$$

where;

$$
\begin{array}{ll}
\text { GDP } & =\text { GDP per capita (\%) } \\
\text { YU } & =\text { Youth Unemployment rate (\%) } \\
\text { INFLA } & =\text { Inflation rate }(\%)
\end{array}
$$

Since this study will run for 10 ASEAN countries $(N)$ and number of observations is 24 years $(T)$, where the $N<T$, the heterogeneous dynamic panel data will be employed. In other words, this study will be employed panel Autoregressive Distributed Lag (ARDL), and thus the model can be written as follows:

where:

$$
\mathrm{GDP}_{i \mathrm{t}}=\alpha+\beta_{\mathrm{it}} \mathrm{YU}_{\mathrm{it}}+\beta_{2} \text { INFLA }_{i \mathrm{t}}+\mu_{\mathrm{it}}
$$

$$
\begin{array}{ll}
\text { GDP it } & =\text { GDP per capita at country } i \text { over the period of } t \\
Y_{\text {it }} & =\text { Youth unemployment rate at country } i \text { over period of } t \\
\text { INFLA }_{\text {it }} & =\text { Inflation rate country } i \text { over period of } t \\
\alpha & =\text { constant } \\
\beta & =\text { coeffiecient } \\
\mu & =\text { error term }
\end{array}
$$

\section{Data and Variable}

This study uses secondary time series data from year 1996 to 2019 from 10 ASEAN countries. The selected ASEAN countries were chosen which are Brunei Darussalam, Cambodia, Indonesia, Lao PDR, Myanmar, Malaysia, Philippines, Singapore, Thailand and Vietnam. The data used in this study is annual data and aggregated data, which taken from World Bank database. The data taken for longer period to ensure the time periods are comparable and required to achieve a good base. There will be a total of 240 numbers of observations in this study.

\section{Descriptive Analysis}

The basic features of the data in the investigation are described using descriptive analysis. When doing descriptive analysis, we simply describe what the data is or indicates. The short summaries of the sample and observations that have been incorporated into the research are shown in descriptive analysis. Descriptive statistics are a type of measurement that gathers 
two different types of data: location and variability. The arithmetic mean is the most frequent method of measurement, and location or the central tendency measurement which to indicate a variable of its central value. Variability, such as variance and standard deviation, was applied to spread the data out from the center. The standard deviation of a series is a measure of its spread or dispersion. The Skewness assesses the lack of symmetry in data distribution, according to Roser et. al (2019). It distinguishes between extreme values in one tail and the other. Kurtosis is a measure of the number of outliers in a distribution.

\section{Estimation Procedure}

When the data set contains both time series and cross-sectional studies, the panel estimation technique is the most appropriate tool. Even panel estimation allows more flexibility (Green, 2010) and improves the results' power due to the bigger sample size (Hondroyiannis, 2010), panel data still have to deal with autocorrelation (time series) and heterogeneity (cross sectional) problems. Endogeneity problem also arise and lead to biased and inconsistent estimators if using fixed effects and random effects models (Bun \& Sarafidis, 2015). Since this study is a micro panel data i.e. $N=10$ countries with $T=24$, the Lagrange Multiplier (LM) test is applicable (Baltagi et al., 2016).

Therefore, the analysis begins with the panel unit root test, where the total of time periods is more than he cross sections number to determine the stationary properties of the relevant variables. After determining the order, the integration of each of the variables of the time series, and if the variables are, results as integrations of different orders, when the existence of both level $I(0)$ and first difference $I(1)$, but strictly speaking not $I(2)$, the Autoregressive Distributed Lag (ARDL) panel test is used to test the cointegration or long-term relationship among the variables of the model.

\section{Panel Unit-Root Test}

By implementing panel data, it is possible to prevent the presence of spurious regression. The estimation of panel data spurious regression yields a consistent estimate of the true value of the parameter when using panel data. Even though panels are more representative than individual time series, unit root tests based on panels have higher power than unit root tests based on individual time series. The panel unit root tests are similar with time series unit root test but not identical (Baltagi et al., 2005).

The panel unit root with heterogeneous dynamics, fixed effects, and an individual specific determinant trend was first studied by Levin, Lin, and Chu (2002) or LLC. In the alternative, they assumed the presence of a homogenous autoregressive root. Im, Pesaran, and Shin (2003), often known as IPS, presented the between-group panel unit root tests, which allow for heterogeneity of the autoregressive root in the alternative. As a result, Choi (2001); Maddala and Wu (1999) proposed employing a Fisher statistic to do the same sorts of panel unit root tests.

In all unit root tests, the null is the presence of a unit root in a sequence of tests. Nevertheless, in the tests provided by LLC, the term "stationary" is used as a confusing alternative. Furthermore, in the IPS test, as well as the Fisher-ADF and Fisher-PP tests, there are some cross sections that do not have a unit root at all. In light of this, we ran the LLC tests under the assumption of a single common unit root process. Meanwhile, using the ADF and PP tests, it was discovered that the assumptions of each unit root processes in the IPS test were consistent with the Fisher-type tests applying the test of ADF and PP. The unit root test on a panel is comparable but it does not mean can indistinguishable on a single series unit 
root test since it is performed using a single series. This is accomplished by categorising the results of our unit root test according to whether or not the existence or limitation for the series or cross-sections by the autoregressive (AR) process. For panel data, we consider the following AR (1) technique to be appropriate:

where:

$$
\mathrm{y}_{\mathrm{it}}=\rho_{\mathrm{i}} \mathrm{y}_{\mathrm{it}-1}+\mathrm{X}_{\mathrm{it}} \delta_{\mathrm{i}}+\varepsilon_{\mathrm{it}}
$$

$i \quad=1,2 \ldots N$ units of cross-section, observation of the periods

$t \quad=1,2 \ldots T$ number of observations

$\mathrm{X}_{\mathrm{it}} \quad=$ exogenous variables, including fixed effects or individual trends

$\rho_{\mathrm{i}} \quad=$ coefficients of autoregressive

$\varepsilon_{\mathrm{it}} \quad=$ idiosyncratic disturbance

If, $|\rho i|<1 Y i$ is said to be weakly (trend) stationary. On the other hand, if If, $|\rho i|=$ 1 then $y_{i}$ contains a unit root. The LLC tests suspect that the unit root process is the same across all cross-sections, and that $\rho_{i}$ is the same across all cross-sections. The LLC test suggest a more powerful panel unit root test than performing individual unit root tests for each crosssection (Baltagi et al., 2005). For example, the LLC test consider the basic ADF specification:

$$
\Delta y_{i t}=\alpha y_{i t-1}+\sum_{j=1}^{\rho_{i}} \beta_{i j} \Delta y_{i t-j}+X_{i t}^{\prime} \delta+\varepsilon_{i t}
$$

where:

$\alpha \quad=1-\rho$ the lag order for the difference terms should be recognised.

Therefore,

$\rho_{i} \quad=$ vary across cross-sections

$\mathrm{H}_{0}: \alpha=0$ (There is unit root/non-stationary)

$\mathrm{H}_{1}: \alpha<0$ (There is no unit root)

Meanwhile, the IPS allow for individual unit root processes so that $\rho_{i}$ vary across crosssections. In this test, we will combine all the individual unit root tests are performed in order to produce a panel-specific result. For example, the IPS tests also beginning with each cross section, specify a separate ADF regression using the following syntax:

$$
\Delta y_{i t}=\alpha y_{i t-1}+\sum_{j=1}^{\rho_{i}} \beta_{i j} \Delta y_{i t-j}+X_{i t}^{\prime} \delta+\varepsilon_{i t}
$$

The null hypothesis for IPS is:

$$
\begin{aligned}
& \mathrm{H}_{0}: \alpha_{\mathrm{i}}=0 \text {, for all } i \\
& H_{1}:\left\{\begin{array}{l}
\alpha_{i}=0 \text { for } i=1,2,3,4, \ldots \ldots, N_{1} \\
\alpha_{i}<0 \text { for } i=N+1, N+2 \ldots ., N
\end{array}\right.
\end{aligned}
$$

Hence, in this research the researcher will apply the panel root test to run and get the result to investigate the unit root for each individually (10 ASEAN countries). Then IPS unit root test will be employed to investigate for the panel unit root test.

\section{Panel Co-integration}

There has been an increased a strong emphasis on the implementation of various statistical tests to panels of data, owing to the increased great interest in and availability of panel data. 
The study of co-integration in a panel context has attracted attention recently. Fisher-type test, Kao (1999) and Pedroni $(1999,2004)$ with fundamental approach of Johansen are the sorts of panel co-integration tests we apply (Maddala \& Wu, 1999). The Engle and Granger (1987) two-step (residual-based) co-integration test is the basis for the Pedroni and Kao test. The Fisher test is a combination of the Johansen and the Fisher tests.

The co-integration test developed by Engle and Granger (1987) is based on an evaluation of the residuals of a spurious regression by using integrated of order (I)(1) variables. The residuals will be I if the variables are co-integrated (0). The residuals, on the other hand, will be I if the variables are not co-integrated (1). The Engle-Granger framework is extended to panel data testing by Kao (1999) and Pedroni $(1999,2004)$. Pedroni presents a number of co-integration tests that allow for different intercepts and trend coefficients across cross-sections. The Kao (1999) test uses the same fundamental approach as the Pedroni tests, but the first-stage regressors have cross-section-specific intercepts and homogenous coefficients. The regression considers as:

where:

$$
y_{i t}=\alpha_{i t}+\chi_{i t} \beta+u_{i t}(1)
$$

$\alpha_{i t}=$ individual constant terms

$\beta=$ slope parameter

Kao proposes an ADF statistic. The DF statistic, which allows for endogeneity. The Augmented-Dickey-Fuller (ADF) type test can be calculated from:

$$
u_{i t}=\rho u_{i t-1}+\sum_{j=1}^{p} \psi_{j} \Delta \mathrm{u}_{i t-j}+e_{i t}
$$

where $\rho$ is chosen so that the residuals $e_{i t}$ are serially uncorrelated. The ADF test statistic is the usual t-statistic with $\rho=1$ in the ADF equation.

Pedroni $(2000,2004)$ suggested that the test of several for panel data model in cointegration allows the consideration of heterogeneity. The benefit of Pedroni tests are the fact they allow for multiple regressor. The cointegration vector to vary across the different in panel sections, and also for heterogeneity in the errors across cross-sectional units. The panel regression model suggested by Pedroni as:

$$
Y_{i t}=a_{i}+\delta_{i}+\sum_{m=1}^{M} \beta_{m i} X_{m i, l}+u_{i t}
$$

where $t=1,2, \ldots, T$ and $n=1,2, \ldots, N ; m=1,2, \ldots M ; Y$ and $X^{\prime}$ s are assumed to be integrated of order one, e.g /(1). The individual $\left(a_{i}\right)$ and trend effect $\delta_{i}$ if desired, it maybe set zero. Nevertheless, the general approach is to obtained residuals from long-run regression and test whether residuals are $/(1)$ by running the auxiliary regression as:

$$
u_{i t}=p_{i} u_{i t-1}+\sum_{j=1}^{p i} \psi_{i j} \Delta u_{i t-j}+e_{i t}
$$

\section{Pooled Mean Group Estimator}

As it contains two pooling and averaging methods, the Pooled Mean Group (PMG) estimator is an intermediate approach. The PMG approach, unlike the MG estimator, typically limits the long-coefficient become homogeneous across individual countries, similar to the dynamic fixed effects estimator. PMG. On the other hand, since it allows for changes in the intercept, short run coefficients, and error variances, the MG estimator is a powerful and flexible estimator. The long-slope coefficient is restricted to being the same across all countries, but the short-coefficients, such as adjustment speed and regression intercept, are allowed to be 
country specific. Due to the ensure the adequacy for this study data collection, panel ARDL model is applied. First, unlike this study, it can allow a mixture of stationarity of variables such as $I(0)$ and $I(1)$ rather than $I(2)$. It's also appropriate for investigations with a modest number of participants. This study has 10 cross sections and 24 years, which is a modest sample size for most panel studies but can be accommodated in panel ARDL models. Finally, it captures the short- and long-term changes of the variable of interest. As a result, both PMG and MG estimations are performed in this study. In the panel ARDL form of Pesaran and Smith (1999), Eq. (1.3) can be expressed as:

$$
\begin{aligned}
& \Delta G D P_{i t}=A+\phi G D P_{i t-1}+\alpha_{i} \sum_{i=1}^{\rho} \Delta G D P_{i t-1}+\pi_{i} \sum_{i=1}^{\rho} \Delta Y U_{i t-1}+ \\
& \omega_{i} \sum_{i=1}^{\rho} \Delta I N F L A_{i t-1}+\lambda_{i} \sum_{i=1}^{\rho} \Delta Y U_{-} I N F L A_{i t-1}+\beta_{1} G D P_{i t-1}+\beta_{2} Y U_{i t-1}+ \\
& \beta_{3} I N F L A_{i t-1}+\beta_{4} Y U_{I_{N F L A}}+\eta_{i}+\varepsilon_{i t}
\end{aligned}
$$

Where $\phi$ is the coefficient of the past lagged value of the dependent variable, $\alpha_{i}, \pi_{i}$ $\omega_{i}$, and $\lambda_{i}$ are the short run coefficients while $\beta_{1}$ to $\beta_{4}$ indicate the long run coefficients with $Y U_{-} I N F L A_{i t-1}$ and $Y U_{-} I N F L A_{i t-1}$ being the short run and the long run interactive effects of remittances and financial development. The MG estimator, on the other hand, can be phrased as Pesaran and Shin (1995) suggest:

$$
M G=N^{-1} \sum_{i=1}^{N} \bar{\beta}_{i}
$$

In Equation (1.12), MG and $\beta_{1}$ denote mean group and coefficient estimates, respectively. After the estimation of the MG and PMG models, the Hausman test is used to determine the homogeneity of long run coefficients in order to find the best model. To provide full and accurate estimates, multiple analysis is used in conjunction with other techniques to overcome econometric problems such as heterogeneity, non-stationarity, dynamics and endogenousness. There is a strong argument that the correlations between variables are homogeneous, especially over extended periods of time, which supports the accuracy of the PMG estimator in this case.

\section{Panel Granger-Causality Test}

Panel Granger causality is used to assess the importance of a given item and the amount of information it contains, as demonstrated by the term's common usage. Using the Granger (1969) method to the condition of whether will causes $y$, one can determine how much the recent $y$ can be explained by the values of $y$ that occurred in the past. Then, to find out the explanation of adding lagged values of $x$ can be improved. As an example, when the coefficients on the lagged $x$ 's are statistically significant, the variable $y$ is said to be Grangercaused by the variable $x$. When there is equal, the variable $y$ is said to be Granger-caused by the variable $x$. It is important to note that two-way causation is frequently observed; $x$ Granger causes $y$ and $y$ Granger causes $x$. It is important to note that the statement "x Granger causes $y$ " does not imply that the result of $x$ or the affection is the same as the cause. In the case of bivariate regressions, the form:

$$
\begin{aligned}
& Y t=\alpha 0+\alpha 1 Y t+\cdots+\alpha l Y t-1+\beta 1 X t-1+\cdots+\beta l X-1+\epsilon t \\
& X t=\alpha 0+\alpha 1 X t+\cdots+\alpha l X t-1+\beta 1 Y t-1+\cdots+\beta l Y-1+\epsilon t
\end{aligned}
$$


to identify all of the possible pairs of $(x, y)$ series in the group The Wald statistics for joint hypotheses are the F-statistics that are reported as follows:

$$
\beta 1=\beta 2=\cdots \beta l=0
$$

The null hypothesis is that does GDP not Granger-cause YU in the first regression and that does YU not Granger-cause GDP in the second regression. The second null hypothesis is that does GDP not Granger-cause INFLA in the first regression and that does INFLA not Granger-cause GDP in the second regression. The third null hypothesis is that does YU not Granger-cause INFLA in the first regression and that does INFLA not Granger-cause YU in the second regression.

\section{Multivariate Analysis of Variance (MANOVA)}

MANOVA test also called multivariate analysis of variance applied as an extension of univariate analysis of variance (ANOVA), in which the independent variable has some combination of group membership, but there is more than one dependent variable, as opposed to univariate analysis of variance (ANOVA). The researcher uses MANOVA to discover the correlation dependent variables, or instead of a repeated-measures ANOVA, to circumvent the sphericity assumption in the ANOVA. MANOVA can be used to assess numerous dependent variables at the same time in a single, more powerful test.

Canonical correlation, which is a specific case of MANOVA, and discriminant function analysis, which are both intimately related to each other (DFA). The assumption of DFA is they assume the group membership is based on the measurement of multiple interval which can be applied after MANOVA to interpret the results. MANOVA is a tool that to review and underlying theory of univariate ANOVA and also as well as demonstrating how it extends ANOVA by two dependent variables. MANOVA recruits two or more dependent variables compare the ANOVA only have one dependent variable (Stockburger,2018). Hence, null hypothesis as below:

$\mathrm{H}_{0}$ : The variable or the interaction of the corresponding has no significant effect on the dependent variables in ASEAN countries

$\mathrm{H}_{1}$ : The variable or the interaction of the corresponding has a significant effect on the dependent variables in ASEAN countries

As mentioned above, MANOVA is extends of ANOVA. Therefore, to determine the variance of the $S$ matrices are found. Wilks' $\lambda$ is the test statistic preferred for MANOVA, and is found through a ratio of the determinants:

$$
\Lambda=\frac{\left|S_{\text {error }}\right|}{\left|S_{\text {effect }}+S_{\text {error }}\right|}
$$

F estimation can be specified through the following equations:

$$
F_{\text {approximax }}\left(d f_{1}, d f_{2}\right)=\left(\frac{1-y)}{y}\right)\left(\frac{d f_{2}}{d f_{1}}\right)
$$

where,

$$
\begin{aligned}
& d f_{1}=p\left(d f_{\text {effect }}\right) \\
& d f_{2}=s\left[\left(d f_{\text {error }}\right)-\frac{p-d f_{\text {effect }}+1}{2}\right]-\left[\frac{p\left(d f_{\text {effect }}\right)-2}{2}\right]
\end{aligned}
$$




$$
\begin{aligned}
& s=\sqrt{\frac{p^{2}\left(d f_{\text {effect }}\right)^{2}-4}{p^{2}+\left(d f_{\text {effect }}\right)^{2}-5}} \\
& y=\Lambda^{1 / 2} \\
& p=\text { No. of } D V_{s} \\
& d f_{\text {effect }}=(I V 1-1)(I V 2-1) \ldots \ldots\left(I V_{n}-1\right) \\
& d f_{\text {error }}=n_{\mathcal{L} 1} * n_{\mathcal{L} 2}\left(n_{D V}-1\right)
\end{aligned}
$$

Lastly, we need to determine the strength of the association. Due to the fact that Wilks' is equal to the variance not accounted for by the combined Dependent Variables, the variance accounted for by the optimal linear combination of Dependent Variables is equal to $(1-\lambda)$.

$$
n^{2}=1-\Lambda
$$

However, so it is calculated as the sum of all Dependent Variables, it can be more than one and consequently less useful than the following formula:

$$
n^{2}=1-\Lambda^{1 / 5}
$$

Wilks' $\lambda$ is the pooled ratio of error variances to the sum of effect variance and error variance plus the sum of error variance. Although this is the most frequently reported test statistic, it is not necessarily the best choice. This function returns an exact F-statistic.

Statistically, the Hotelling's trace is defined as the pooled ratio of effect variance to error variance:

$$
T=\sum_{i=1}^{s} \lambda_{i}
$$

The Pillai-Bartlett criterion is equal to the sum of the pooled effect variances. The most robust and powerful test statistic is frequently believed to be the chi square test statistic. It is the case Provides the most cautious F-statistic possible

$$
V=\sum_{i=1}^{s} \frac{\lambda_{i}}{1+\lambda_{i}}
$$

Finally, Roy's Largest Root, which refers to the eigenvalue with the greatest magnitude. Additionally, it disregards the F-statistic if none of the other test statistics are significant, resulting in an upper bound for the F-statistic. As a result, when there are moderate correlations between dependent variables, MANOVA can produce a suitable result in the consequence (French, Macedo, Poulsen, J., Waterson, \& Yu, 2008).

\section{Empirical Result \\ Descriptive Statistics}

Due to this research having a large amount of data, descriptive statistics is important to help find out how to simplify large amounts of data in a sensible way. Summary statistics for the Gross Domestic Product, Youth Unemployment, and INFLA are shown in Table 2. As refer to Table 2, the measures of central tendency for the variables all show a positive direction. Standard deviation reflects how far the sample mean is from the 'actual' population mean in terms of standard error. It rises in proportion to the increase in variation, and falls in proportion to the increase in sample size. It offers a measure of ambiguity in the data. GDP, 
YU, and INFLA all have standard deviations of $3.651,7.878$, and 12.554 correspondingly, while GDP is the most volatile.

Table 2: Descriptive Statistics of the Variables ASEAN Countries

\begin{tabular}{|l|c|c|c|}
\hline \multicolumn{1}{|c|}{ Category } & GDP & YU & INFLA \\
\hline Mean & 3.876 & 10.647 & 6.392 \\
\hline Median & 4.358 & 9.281 & 3.406 \\
\hline Maximum & 12.788 & 36.657 & 125.272 \\
\hline Minimum & -14.351 & 1.357 & -2.315 \\
\hline Std. Dev. & 3.651 & 7.878 & 12.554 \\
\hline Skewness & -0.916 & 0.861 & 5.815 \\
\hline Kurtosis & 6.522 & 3.031 & 45.980 \\
\hline
\end{tabular}

Source: Authors Computation

As the result for skewness, since the result for GDP shows the values in negative such as -0.916 skewed negatively with left-hand tail. But YU and inflation shows the values in positive as $0.861,5.815$ where there is positively skewed, and the right-hand tail will be longer than the left-hand tail. Moreover, the Kurtosis result also shows that the value of GDP, YU and INFLA are more than 3 as $6.522,3.031$ and 45.980 where there is less variability where it's called Leptokurtic with the peaks sharply with tails. The distribution is longer, tails are fatter. Peak is higher and sharper than Mesokurtic, which means that data are heavy-tailed or profusion of outliers.

\section{Mean Group and Pooled Mean Group: Hausman Test Results}

In this section, both PMG and MG estimators will be applied. The optimal lag length of panel ARDL $(4,4,4)$ is chosen for both the PMG and MG estimations following the Schwarz information criterion (SIC). The validity of the long-run homogeneity restriction cross countries and the efficiency of the PMG estimator over the MG estimator were then examined by the Hausman test. In this test, the null hypothesis is that the difference between PMG and MG is not significant. If we cannot reject the null hypothesis, the PMG estimator is efficient. 
Table 3: Mean Group and Pooled Mean Group: Hausman Test with ARDL $(4,4,4)$ Results

\begin{tabular}{ccccc}
\hline & \multicolumn{2}{c}{ Pooled Mean Group (PMG) } & \multicolumn{2}{c}{ Mean Group (MG) } \\
\hline $\begin{array}{c}\text { GDP (Dependent } \\
\text { Variable) }\end{array}$ & Long Run & Short run & Long Run & Short run \\
\hline EC & & $0.226^{* * *}$ & & $0.364^{* * *}$ \\
& & $(0.000)$ & $(0.000)$ \\
\hline$\Delta$ YU & 0.041 & & 0.166 \\
& & $(0.852)$ & $(0.683)$ \\
\hline INFLA & $-0.073^{* * *}$ & & $0.105^{* * *}$ \\
& & $(0.012)$ & $(0.001)$ \\
YU & $-0.246^{* * *}$ & & -2.679 & \\
& $(0.000)$ & & $(0.400)$ & \\
\hline INFLA & $0.311^{* * *}$ & & -0.039 & \\
& $(0.000)$ & & $(0.880)$ & -0.539 \\
\hline Constant & & $-1.177^{* * *}$ & & \\
& & $(0.000)$ & $0.590)$ \\
\hline Observation & 200 & & 200 & \\
\hline Hausman Test & & 0.56 & \\
& & & $0.756)$ & \\
\hline
\end{tabular}

Note: ${ }^{* * *}$ indicate significance at 1 percent. Estimations are done by using (xtpmg) routine in Stata. Pooled mean group and mean group all controlling for country and time effects while the first panel (LR) shows long-run effects. The second panel reports both short-run effects (SR) and the speed of adjustment (EC). The order of variables is: GDP, Youth unemployment and Inflation.

Source: Authors Computation

Based on the result on Table 3 reports the results of PMG and MG that the measurement for the comparative efficiency and consistency. The results revealed that according to PMG estimator, in long run youth unemployment (YU) has a significant in negative impact where the increase in 1percent of youth unemployment, it will decrease 0.24 percent of economic growth which is in line with the findings by (Evanezza \& Caroline, 2020). Somehow, there is no impact in the short run on economic growth (GDP) meanwhile the MG estimator shows there also negative but insignificant coefficient for both long run in short run. For inflation (INFLA), the result stated that INFLA also has a positive significant impact in the long run which means that the increase of 1percent of inflation, it also improves the economic growth with 0.31percent. But there is negative significance in short run-on economic growth (GDP) according to the PMG estimator, whereas the MG estimator indicates that it has no impact on economic growth in the long run but positive significant impact in the short run. For the result speed adjustment (EC), the result indicated that there is a short run impact for both PMG and MG estimator which is positive significant. Therefore, the Hausman test accepted the null hypothesis which revealed that PMG was a more accurate and efficient estimator than the MG model after comparing both estimators. We can clearly find that the PMG estimator is more favorable than the MG estimator.

\section{Robustness Analysis}

In this section Robustness analysis will be applied to find the valid causal inference and the coefficients of the model (White et al., 2010). Generally, it is important to have a robustness test especially the sensitive analysis to avoid the appearance of "fragility" of regression 
coefficient estimates is inactive of specification error in research (Leamer, 1983). Hence, the comparison between Pooled Mean Group (PMG) estimator Dynamic Fixed Effect (DFE) estimator will be applied to define the strength of the model.

Table 4: Robustness Analysis Result

\begin{tabular}{lllll}
\hline & \multicolumn{2}{c}{ Pooled Mean Group (PMG) } & \multicolumn{2}{c}{ Dynamic Fixed Effect (DFE) } \\
\hline $\begin{array}{l}\text { GDP (Dependent } \\
\text { Variable) }\end{array}$ & Long Run & Short run & Long Run & Short run \\
\hline EC & & & \\
& & $0.226^{* * *}$ & & $0.330^{* *}$ \\
& $(0.000)$ & & $(0.000)$ \\
\hline$\Delta$ YU & & 0.041 & $-0.107^{* * *}$ \\
& & $(0.852)$ & $(0.001)$ \\
\hline$\Delta$ INFLA & & $-0.073^{* * *}$ & & -0.008 \\
& & $(0.012)$ & & $(0.073)$ \\
\hline YU & $-0.246^{* * *}$ & & 0.000 & \\
& $(0.000)$ & & $(0.999)$ & \\
\hline INFLA & $0.311^{* * *}$ & & 0.007 & \\
& $(0.000)$ & & & \\
\hline Constant & & $-1.177^{* * *}$ & & $-1.322^{* * *}$ \\
& & $(0.000)$ & & $(0.000)$ \\
\hline Observation & 200 & & 200 &
\end{tabular}

Note: $* * *$ Significance at 1 per cent

Source: Authors Computation

According to table 4, the result is comparing the PMG and DFE model which affirm the robust analysis. The results revealed that according to PMG estimator, youth unemployment (YU) has a negative significant impact in the long run and no impact in the short run-on economic growth (GDP) meanwhile the DFE estimator shows there has no impact on economic growth in long run but have negative with significant impact in the short run. For inflation (INFLA), the result stated that INFLA also has positive significant impact in the long run but negative impact significant in short run-on economic growth (GDP). Hence, the result revealed that the DFE model has no significant impact of inflation (INFLA) on economic growth (GDP) in both long run and short run. For EC, the result indicated that there is a short run impact for both PMG and DFE model, which is negative. Therefore, it is sufficient for the constraint of homogeneity across the countries in the long run and the validity of the PMG estimator through the other two estimators as MG and DFE. As a conclusion, the comparison between PMG and DEF, it is like an expected PMG estimator is favorable over DFE mode. As a result, there is affirmation that in the long-term there exists a causal relationship between economic growth (GDP), youth unemployment (YU), and inflation (INFLA).

\section{Correlation Matrix}

In this section, the diagnostic test is cross-sectional correlation test, panel unit root test, crosssection dependence test and panel cointegration. The implementation of these tests will help to determine the model and how to estimate it. Correlation analysis will proceed to determine the direction and strength between the variables. In addition, the analysis also indicates how the data are correlated with measurement of multicollinearity. From table 5 method of 
correlation test to test multicollinearity, how the data is free from high multicollinearity of the variables between economic growth (GDP), youth unemployment (YU) and inflation (INFLA) in ASEAN countries.

Table 5: Correlation Matrix Result for ASEAN Countries

\begin{tabular}{|l|l|l|l|}
\hline & GDP & YU & INFLA \\
\hline GDP & 1.000 & & \\
\hline YU & -0.285 & 1.000 & \\
\hline INFLA & 0.083 & -0.188 & 1.000 \\
\hline
\end{tabular}

Source: Authors Computation

Based on the result shown in table 5, It shows that the variables of economic growth (GDP), youth unemployment (YU), and inflation (INFLA) in ASEAN countries have a linear relationship. As the result indicated that all variables below the threshold value of multicollinearity which is to be 80 percent or anything below 90 percent and also not nearly only dependent on one another. Therefore, no multicollinearity exists in this model and no variable is needed to be excluded. Hence, the estimators still remain unbiased, efficient and consistent. Hence, it can be concluded that the problem of multicollinearity does not exist in the model.

\section{Panel Unit Root Test}

Before proceed to panel unit root test, cross-section dependency test be applied due to $T>N$ by Breusch Pagan test in order to find out the suitable type of panel unit root test and to determine the level of cointegration in the research.

Table 6 Cross-Section Dependence Test Result

\begin{tabular}{|l|c|c|}
\hline \multicolumn{1}{|c|}{ Test } & Statistic & $P$-value \\
\hline Breusch-Pagan LM & 211.132 & 0.000 \\
\hline Pesaran scaled LM & 17.512 & 0.000 \\
\hline Pesaran CD & 12.211 & 0.000 \\
\hline
\end{tabular}

Source: Authors Computation

Table 6 revealed that we can reject the null hypothesis of no cross-section dependence in where it is significance at 1 percent of $p$-value. As a result, we can conclude that there is existence of cross-section dependency and Pesaran (2007) test was used for the panel unit root test. After that, the analysis will proceed with the IPS panel unit root test, because the number of time periods is more than the number of cross sections, allowing for the determination of the stationary qualities of the necessary variables to be completed. The estimation of panel data spurious regression yields a consistent estimate of the true value of the parameter when using panel data. The unit root tests based on panels have more significant than the unit root tests based on individual time series since they are more representative. 
Table 7. Panel Unit Root Test Results

\begin{tabular}{|l|l|l|l|l|}
\hline \multicolumn{3}{|c|}{ IPS Test } \\
\hline \multirow{2}{*}{ Variables } & \multicolumn{2}{|c|}{ At Levels } & \multicolumn{2}{c|}{ At First Difference } \\
\cline { 2 - 5 } & Intercept & Intercept \& Trend & Intercept & Intercept \& Trend \\
\hline GDP & $-5.862^{* * *}$ & $-5.983^{* * *}$ & $-18.252^{* * *}$ & $-19.493^{* * *}$ \\
\hline YU & 0.104 & -1.005 & $-6.553^{* * *}$ & $-5.498^{* * *}$ \\
\hline INFLA & $-4.717^{* * *}$ & $-5.470^{* * *}$ & $-17.327 * * *$ & $-16.247^{* * *}$ \\
\hline
\end{tabular}

Note: ${ }^{* * *}$ Significance at 1 per cent

Source: Authors Computation

The IPS panel unit root tests result present in Table 7. The IPS test result stated that all variables of the model are found to be stationary at first difference of significance of 1 percent. Then, we can reject the null hypothesis of stationarity non-existence. The GDP, YU and INFLA are found to be integrated /(1). At this moment, the results of IPS panel unit root test are more favorable according to the cross-section dependency test. Therefore, as all the variables are stationary at mixed level, as for next step, panel cointegration analysis will be carried out in order to determine whether there is a long-term correlation between youth unemployment, inflation, and economic growth in the ASEAN countries.

\section{Panel Co-integration Test}

To proceed the panel co-integration test between GDP, YU and INFLA. In this co-integration test, panel test by using Kao (1999); Pedroni (1999), and Westerlund procedures which contribute GDP to YU and INFLA in the long-run.

Table 8: Panel Co-integration Test Results

\begin{tabular}{|l|l|l|l|}
\hline & \multicolumn{1}{|c|}{ Kao Test } & \multicolumn{1}{|c|}{$\begin{array}{c}\text { Pedroni } \\
\text { Test }\end{array}$} & $\begin{array}{c}\text { Westerlund } \\
\text { Test }\end{array}$ \\
\hline Modified Dickey-Fuller t & -0.005 & & \\
\hline Dickey-Fuller t & $-2.035^{* * *}$ & & \\
\hline Augmented Dickey-Fuller t & $-2.3835^{* * *}$ & $-6.197^{* * *}$ & \\
\hline Unadjusted modified Dickey-Fuller t & $-14.360^{* * *}$ & & \\
\hline Unadjusted Dickey-Fuller t & $-9.203^{* * *}$ & & \\
\hline Modified Phillips-Perron t & & $-2.406^{* * *}$ & \\
\hline Phillips-Perron t & & $-6.614^{* * *}$ & \\
\hline Variance ratio & & & $-2.218^{* * *}$ \\
\hline
\end{tabular}

Note: ${ }^{* * *}$ denotes $1 \%$ significant level.

Source: Authors Computation

Table 8 presents the result of the panel co-integration test. The results show that the three variables are co-integrated. So, it can be clearly confirmed that the panel cointegration test showed there is a long-run relationship between GDP, YU, and INFLA in ASEAN countries. The findings also revealed that most of the statistics at the 1percent significance level reject the null hypothesis of no co-integration. Therefore, this is in agreement with a similar study of unemployment and inflation on economic growth in Nigeria that was conducted by Ademola and Badiru (2016). Thus, it is evident that the model of GDP, YU and INFLA have cointegrated in long-run. 


\section{Panel Granger Causality Results}

In this section, panel Granger causality test will be applied to answer the second objective of this study to find out how much the economic growth can be explained by the values of Youth Unemployment (YU) and Inflation (INFLA) in ASEAN countries.

Table 9 Panel Granger Causality Test

\begin{tabular}{|c|c|c|c|c|c|c|}
\hline & GDP $\rightarrow$ YU & $\begin{array}{c}\text { YU } \rightarrow \\
\text { GDP }\end{array}$ & $\begin{array}{c}\text { GDP } \rightarrow \\
\text { INFLA }\end{array}$ & $\begin{array}{c}\text { INFLA } \rightarrow \\
\text { GDP }\end{array}$ & $\begin{array}{c}\text { INFLA } \rightarrow \\
\text { YU }\end{array}$ & $\begin{array}{c}\text { YU } \rightarrow \\
\text { INLFA }\end{array}$ \\
\hline Panel & $8.263^{* * *}$ & $7.714^{* * *}$ & $4.655^{* * *}$ & $3.717^{* * *}$ & 0.822 & 1.571 \\
\hline
\end{tabular}

Note: ${ }^{* * *}$ Significance at 1 per cent

Source: Authors Computation

Based on table 9, the result indicates that economic growth (GDP) has granger causality with both youth unemployment (YU) and inflation (INFLA) with the significance result and reject the null hypothesis at 1per percent respectively. Moreover, for ASEAN countries as a group, the result indicated that economic growth (GDP) with both youth unemployment (YU) and inflation (INFLA) have bidirectional causality which is GDP granger causality youth unemployment (YU) and inflation (INFLA) with the result of significance at 1percent and youth unemployment (YU) and inflation (INFLA) also can granger causality economic growth (GDP) with the result of significance at 1percent. Therefore, the bidirectional relationship between youth unemployment (YU), inflation (INFLA) and economic growth (GDP) exists with causality running from youth unemployment (YU) and inflation (INFLA) to economic growth (GDP) in ASEAN countries.

\section{Multivariate Analysis of Variance (MANOVA)}

Lastly, Multivariate Analysis (MANOVA) applied in this section which to try to answer the third objective that identify any interaction between youth unemployment (YU), inflation (INFLA) and economic growth in ASEAN countries.

Table 10: MANOVA Result

\begin{tabular}{|c|c|c|c|c|c|}
\hline \multirow{2}{*}{$\begin{array}{c}\text { Effect } \\
\text { GDP }\end{array}$} & \multicolumn{5}{|c|}{ YU*INFLA } \\
\hline & Test & $\mathbf{F}$ & Hypothesis df & Error df & Sign \\
\hline & Wilks's test & 3.275 & 2 & 228 & 0.040 \\
\hline & Hotelling-Lawley's test & 3.275 & 2 & 228 & 0.040 \\
\hline & Pillai's test & 3.275 & 2 & 228 & 0.040 \\
\hline & \multicolumn{5}{|c|}{ GDP*YU } \\
\hline \multirow[t]{5}{*}{ INFLA } & Wilks's test & 3.380 & 2 & 228 & 0.036 \\
\hline & Hotelling-Lawley's test & 3.380 & 2 & 228 & 0.036 \\
\hline & Pillai's test & 3.380 & 2 & 228 & 0.036 \\
\hline & Roy's test & 3.380 & 2 & 228 & 0.036 \\
\hline & \multicolumn{5}{|c|}{ GDP*INFLA } \\
\hline \multirow[t]{4}{*}{ YU } & Wilks's test & 0.140 & 2 & 228 & 0.870 \\
\hline & Hotelling-Lawley's test & 0.140 & 2 & 228 & 0.870 \\
\hline & Pillai's test & 0.140 & 2 & 228 & 0.870 \\
\hline & Roy's test & 0.140 & 2 & 228 & 0.870 \\
\hline
\end{tabular}

Source: Authors Computation 
Wilks' Test, Hotelling-Lawley's test, Pillai's test and Roy's test were applied in the MANOVA test. According to MANOVA, as the computed $p$-value is lower than the significance level alpha $=0.05$, one can reject the null hypothesis which means the interaction of the corresponding variable has a significant effect on the dependent variables. As a result, table 10 shows that the Youth Unemployment (YU)*inflation (INFLA) scores below 0.05 are significant. In addition, the economic growth *Youth Unemployment is significant effect on the inflation (INLFA) where the p-value is below 0.5percent (0.036). Lastly the result also shows that economic growth (GDP)*inflation (INFLA) has insignificant effect on youth unemployment (YU) with $p$-value is $(0.870)$ where the computed $p$-value is higher than the significance level alpha $=0.05$, one we cannot reject the null hypothesis. In conclusion, this indicates that youth unemployment and Inflation are indeed influenced by economic growth which states that economic growth has interaction with both youth unemployment and inflation directly with the significant result and also when economic growth with youth unemployment there is existence of the interaction with inflation in ASEAN countries.

\section{Discussion of the Results}

This research discusses the introduction, explaining the empirical findings of the relationship among youth unemployment, inflation and economic growth in ASEAN. Firstly, we specify the model of this study. Next, the study proceeds to the descriptive analysis of the data. After that, the result of the model of GDP, YU and INFLA are significant with the existing long-run relationship for ASEAN countries. Then, the PMG estimator is more favorable. The results revealed that according to the PMG estimator, in the long run youth unemployment (YU) has a significant negative impact where the increase in 1percent of youth unemployment will decrease 0.24 percent of economic growth. For inflation, the result stated that inflation (INFLA) also has positive significant impact in the long run which means that the increase 1percent in inflation, it also improves the economic growth with 0.31percent and in short run the inflation revealed that there is negative relationship where increase of 1percent in inflation, it will decrease 0.073 unit in economic growth. Hence, these results can fulfill the first objective that examines the relationship between youth unemployment, inflation and economic growth in ASEAN countries. Then, the diagnostic tests are Correlation Matrix test, cross-sectional correlation test, panel unit root tests, cross-section dependence test and panel co-integration tests. The correlation analysis applied to find out there is no multicollinearity problem in the model. The implementation of these tests will help us to determine the model. Next, the result also found out that the model passed an adequate test with no parameter and error variance instability which can conclude that it is satisfied for the model and data observation.

The second finding is to investigate the causality effect between youth unemployment, inflation and economic growth in ASEAN countries. The results indicate that economic growth (GDP) has granger causality with both youth unemployment (YU) and inflation (INFLA) with the significance result and reject the null hypothesis at 1 percent level. Hence, the bidirectional causality relationship existed between the 3 variables in ASEAN countries.

Lastly, multivariate analysis has been applied to identify any interaction between economic growth, youth unemployment and inflation in ASEAN countries. The result stated that the youth unemployment and inflation is indeed influenced by the economic growth which stated that economic growth has interaction with both youth unemployment and inflation directly with the significant result and also when economic growth with youth 
unemployment there is existence of the interaction with inflation in ASEAN countries. In contrast, the result also shows that economic growth and inflation has an insignificant effect on youth unemployment which means there is no interaction when economic growth and inflation are not influenced by youth unemployment.

\section{Conclusion and Recommendation}

In this research, analyzing the relationship between youth unemployment, inflation and economic growth in ASEAN countries, these findings have provided certain important policy and economic implications. At the beginning, the study examines the impact of youth unemployment and inflation on economic growth in ASEAN countries. Secondly, there is the existence of a bidirectional relationship between youth unemployment, inflation and economic growth with causality running from youth unemployment and inflation to economic growth in individuals. Thus, youth department policies must take the changes that are influenced by relevant information as a result where the three variables have a long-term relationship and the result is substantial. Lastly, there is also a finding that youth unemployment (YU) and inflation (INFLA) have an interaction of significant effect on economic growth (GDP). Hence, some policies must be implemented to aid in the enhancement of youth empowerment policies as well as the creation of young employment. As a policy implication, policymakers should enhance output in ASEAN countries by enhancing productivity or supply in order to reduce unemployment and increase the prices of goods and services (inflation), boost economic growth, and offer rational wage range. In addition, the government must widen participation of youth in the workforce and create more jobs in order to reduce youth unemployment and inflation, as well as improve domestic output (GDP) in ASEAN countries.

Since young people are a national asset who must be developed over time and their abilities and skills polished, the issue of unemployment, particularly among the youth, must be aggressively addressed, because they are a national asset who must be developed over time and their abilities and skills polished. Unemployment among young people is a serious problem that cannot be overlooked or dismissed. As previously stated by Zainul and Hadi (2020), ASEAN countries must flatten their separate human development indexes. This is because when there is an imbalance in human development, the youth unemployment rate tends to rise. The findings of this study may help to highlight the link between youth unemployment, inflation, and economic growth in ASEAN. It also exposes social development and those who deal with it efficiently and productively in order to contribute to higher rates of economic growth. For example, to improve productivity in order to increase revenues, which will likely result in more youth employment. As a result, output will improve, necessitating the purchase of more machinery and the investment necessary to construct other factories. As a result, there will be more consumption and investment, which will boost the country's GDP, which is the most widely accepted indicator of economic growth.

As a result, the Okun's theorem is valid in this finding since the empirical results demonstrate that young unemployment and GDP have a negative relationship, indicating that a $1 \%$ rise in youth unemployment will result in a 0.24 percent decline in economic growth. This is consistent with Ademola and Badiru's analysis on the impact of unemployment and inflation on Nigerian economic growth (2016). A coordinated effort between the government, industry stakeholders, and the youth themselves can help to close the industry's existing 
demand-supply gap, and this is something that everyone can support. Furthermore, because there is a bidirectional relationship between YU, INFLA, and GDP in ASEAN countries, the Human Resources Ministry's Department of Skill Development must be staffed by industry experts familiar with the skill sets required of local graduates to meet the needs of ASEAN countries and global industries. Apprenticeship, training, and internship partnerships. Companies can also aid by expanding internship possibilities and cooperating with colleges and universities as well as career centres. To combat skill mismatch, companies can increase on-the-job training for new graduates in their first year. For example, workers in Japan are reskilled during their first year of employment in order to match industry expectations.

\section{References}

Ademola, A. S., \& Badiru, A. (2016). The impact of unemployment and inflation on economic growth in Nigeria (1981-2014), International Journal of Business and Economic Sciences Applied Research (IJBESAR), 9(1), 47-55.

Al- Sawaie, K. M. (2020). The relationship between unemployment and economic growth in Jordan: An empirical study using the ARDL approach. International Journal of Innovation, Creativity and Change, 14(2), 1068-1083.

Amadeo K. (2018). What Is Inflation? How It Is Measured and Managed: Why Inflation Is as Violent as a Mugger. Retrieved from https://www.thebalance.com/what-is-inflationhow-it-s-measured-and-managed-3306170

Aminu, U., Manu, D., \& Salihu, M. (2013). An empirical investigation into the effect of unemployment and inflation on economic growth in Nigeria. Interdisciplinary Journal of Research in Business, 12, 1-14.

Baltagi, B. H., Bresson, G., \& Pirotte, A. (2005). Panel unit root tests and spatial dependence, Texas A\&M University Working Paper in Economics simple test, Oxford Bulletin of Economics and Statistics, 61, 631-652.

Baltagi, H. B., Kao, C., \& Peng, B. (2016). Testing cross-sectional correlation in large panel data models with serial correlation. Journal: Econometrics, 2225-1146(4), 1-24.

Bun, M. J., \& Sarafidis, V. (2015). Dynamic Panel Data Models. In B. H. Baltagi (Ed.), The Oxford Handbook of Panel Data (pp. 76-110). Oxford: Oxford University Press.

Choi, I. (2001). Unit root tests for panel data. Journal of International Money and Finance, 20.

Engle R., \& Granger, C. (1987). Co-integration and error correction: representation,

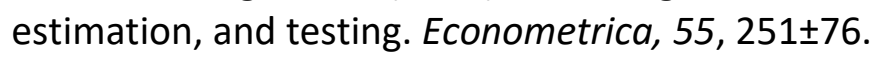

Evanezza M., \& Caroline G. (2020). Macroeconomic factors that affecting youth unemployment in Malaysia. MJBE Malaysia Journal of Business and Economics, 7(2), 181-205.

French, A., Macedo, M., Poulsen, J., Waterson, T., \& Yu, A. (2008). Multivariate analysis of variance (MANOVA). Retrieved from http://userwww.sfsu.edu/efc/classes/biol710/ manova/manovane west.htm

Friedman, M. (1976). Inflation and Unemployment- Nobel Memorial Lecture. Illinois, USA: The University of Chicago.

Granger, C. W. (1969). Investigating causal relations by econometric models and crossspectral methods. Econometrica, 37, 424-438.

Green, D. P. (2010). Using experiments to estimate the effects of education on voter turnout. American Journal of Political Science, 54(1), 174-189.

Hayes A. (2018). Inflation: What is inflation? Retrieved from https://www.investopedia. com /university/inflation/ inflation1.asp 
Hondroyiannis,G. (2010). Fertility determinants and economic uncertainty: An assessment using European panel data. Journal of Family and Economic Issues, 31(1), 33-50.

Ihensekhien, O. A., \& Ozemhoka, A. M. (2017). Youth unemployment and economic growth: Lesson from low-income countries in Sub-Saharan Africa. European Journal of Economics, Law and Politics, 4(2), 1-15.

Im, K. S., Pesaran, M. H., \& Shin, Y. (2003). Testing for unit roots in heterogeneous panels. Journal of Econometrics, 115, 53-74.

International Labour Organization. (2017). Global Employment Trends for Youth 2017: Paths to a better working future. Retrieved from http://www.ilo.org/wcmsp5/ groups/public/---dgreports/---dcomm/---publ/documents/publication/wcms_598669. pdf

International Labour Organization. (2019). Regional conference on reducing youth unemployment: ASEAN's response to the future of work in digital economy. Retrieved from https://www.ilo.org/jakarta/whatwedo/eventsandmeetings/WCMS647645/lang-en/index.htm

International Labour Organization. (2020). Global employment trends for youth 2020: Technology and the future of jobs. Retrieved from https://www.ilo.org/wcmsp5/groups/public/---dgreports/---dcomm/---publ/ docume nts / public ation/wcms_ 737648 .pdf

Kao, C. (1999). Spurious regression and residual-based tests for cointegration in panel data. Journal of Econometrics, 90, 1-44.

Khan, M. S., \& Senhadji, A. S. (2001). Threshold effects in the relationship between inflation and growth (IMF Working Paper 48) Retrieved from https://www.imf.org/external/pubs/ft/wp/2000 /wp00110.pdf

Leamer, E. (1983). Let's take the con out of econometrics. American Economic Review, 73(1), 31-43.

Levin, A., Lin, C. F., \& Chu, C. (2002). Unit root tests in panel data: Asymptotic and finitesample properties. Journal of Econometrics, 108, 1-24.

López-Villavicencio, A., \& Mignon, V. (2011). On the impact of inflation on output growth: Does the level of inflation matter?. Journal of Macroeconomics, 33, 455-464.

Maddala, G. S., \& Wu, S. (1999). A comparative study of unit root tests with panel data and a new. Oxford Bulletin of Economics and Statistics, 61, 631-652.

O'Higgins, N. (2010). The impact of the economic and financial crisis on youth employment: Measures for labour market recovery in the European Union, Canada and the United States. (Employment Working Paper No. 70).

Okun, A. (1962). Potential GNP: Its measurement and significance. In Business and Economic Statistics Section, 98-104. American Statistical Association.

Pedroni, P. (1999). Critical values for Cointegration tests in heterogeneous panels with multiple Regressors. Oxford Bulletin of Economics and Statistics, 61, 653-670.

Pedroni, P. (2004). Panel cointegration: Asymptotic and finite sample properties of pooled time series test with an application to the PPP Hypothesis (Working Papers No 2004-15). Retrieved from https://www.researchgate.net/publication/23564877

Pesaran H., Shin, Y., \& Smith, R. (1999). Pooled mean group estimation of dynamic heterogeneous panel. Journal of the American Statistical Association, 94, 621-634.

Pesaran, H., \& Shin, Y. (1999). Chapter 11: An autoregressive distributed lag modelling approach to cointegration. In Econometrics and Economic Theory in the 20th Century: The Ragnar Frisch Centennial Symposium. Cambridge University Press. 
Pesaran, H., \& Smith, R. (1995). Estimating long-run relationships from dynamic heterogeneous panels. Journal of Econometrics, 68, 79-113.

Pesaran, M. H. (2007). A simple panel unit root test in the presence of cross-section dependence. Journal of Applied Econometrics, 22, 265-312.

Pesaran, M. H., \& Shin, Y. (1995). An autoregressive distributed lag modeling approach to cointegration analysis (Cambridge Working Papers in Economics 9514). Faculty of Economics, University of Cambridge.

Roser, B., Jaume, A., Rafael, A., \& Maria, J. B. (2019). Bias, precision, and accuracy of skewness and kurtosis estimators for frequently used continuous distributions. Symmetry 2020, 12(1), 19. https://doi.org/10.3390/sym12010019

Seleteng, M., Bittencourt, M., \& Eyden, R. (2013). Non-linearities in inflation-growth nexus in the SADC region: A panel smooth transition regression approach. Economic Modelling, 30, 149-156.

Vinayagathasan, T. (2013). Inflation and economic growth: A dynamic panel threshold analysis for Asian economies. Journal of Asian Economics, 26, 31-41.

White, H. C., Smith, E. B., \& Bothner, M. S. (2001). A model of robust positions in social structure. American Journal of Sociology, 116(3).

World Bank. (2020). Unemployment, youth total (\% of total labor force ages 15-24). Modeled ILO Estimate. Retrieved from https://data.worldbank.org/indicator

Zainul, H., \& Hadi, S. (2020). Determinants of youth unemployment rate in Asean. International Journal of Scientific \& Technology Research, 9(3), 6687-6691. 